\title{
Anatomia dyktatora Schramma a interpretacje Hitlera. Przyczynek do krytyki
}

$\mathrm{H}^{\mathrm{i}}$ ipnotyczne zainteresowanie, jakie wywołuje we współczesnych badaczach różnych dziedzin, postać Hitlera i wydarzenia III Rzeszy, przypomina przywoływanego przez Waltera Benjamina anioła historii z obrazu Klee. „(...) Wygląda, jak gdyby chciał się oddalić od czegoś, w co się uporczywie wpatruje. Oczy szeroko rozwarte, usta otwarte, skrzydła rozpięte. (...) Zwrócił oblicze ku przeszłości"1. Podobnie, jak ów Angelus Novus, tak refleksja nad historią Niemiec XX wieku, spogląda w przeszłość uporczywie, próbując odnaleźć odpowiedź na nurtujące ją pytania, z których większość, jeśli nie wszystkie, wiążą się z Hitlerem. Pytają: „Kiedy to się zaczęło? Jak? Dlaczego eskalowało do katastrofy? Kto zawinił? Jakie bóstwo obraził? Jak można je ubłagać?" ". Z pewnością jest wiele prawdy w Assmannowskim twierdzeniu, że wina stanowi wyjątkowo mobilizujący czynnik, ,jest szczególnie silnym, ale nie jedynym impulsem wspomagającym wysiłek przypominania sobie i rekonstruowania przeszłości" ${ }^{3}$. Obarczeni brzemieniem dokonań reżimu nazistowskiego, na czele z eksterminacją Żydów ${ }^{4}$, od razu po wojnie Niemcy musieli się zmierzyć z winą, w czym ,pomagali” im alianccy zwycięzcy, którzy przystąpili do denazyfikacji ,jądra ciemności". Pierwszym krokiem ku temu miały być procesy sądowe ${ }^{5}, \mathrm{~m}$. in. procesy norymberskie (20 XI 1945-1

W. Benjamin, o pojęciu historii, [w:] tenże, Anioł historii. Eseje, szkice, fragmenty, przeł. K. Krzemieniowa, H. Orłowski, J. Sikorski,Poznań 1996, s. 418.

J. Assmann, Pamięć kulturowa. Pismo, zapamiętywanie i polityczna tożsamość w cywilizacjach starożytnych, przeł. A. Kryczyńska-Pham, Warszawa 2008, s. 256.

Tamże, s. 257.

G. Agamben argumentuje, że nie powinno się stosować terminu Holokaust. Słowo to oznaczało bowiem najwyższą ofiarę, składaną w geście oddania się sprawom wyższym i świętym. Uznanie śmierci ludzi w piecach krematoryjnych za „najwyższą ofiarę" sprawom III Rzeszy zakrawa - wedle autora - na absolutną ignorancję. Por. G. Agamben, Co zostaje z Auschwitz?, przeł. S. Królak, Warszawa 2008, rozdział I. Podobnie A. Besançon: „Pewni Żydzi odrzucili słowo Holocaust [holokauston], ponieważ oznaczając ofiarę, nie może oznaczać obłędnego paroksyzmu zła, i woleli słowo: Szoah, „katastrofa” (A. Besançon, Przekleństwo wieku, przeł. J. Guze, Warszawa 2000, s. 99).

Por. U.-D. Oppitz, Postępowanie karne i wykonanie kary przy zbrodniach hitlerowskich, przeł. W. Hanczakowski, Warszawa 1980. 
X 1946) ${ }^{6}$ czy procesy oświęcimskie ${ }^{7}$, a także głośny proces Eichmanna z 1961 roku - głośny przede wszystkim dlatego, że oskarżonego porwały z Argentyny izraelskie służby specjalne.

Wydaje się jednak, że istnieje coś więcej niż jedynie chęć prawnej oceny, co powoduje ciągłe wpatrywanie się „oczami szeroko rozwartymi" w Hitlera. „Tylko znacząca przeszłość jest wspominana i tylko wspominana przeszłość staje się znacząca”" . Jeśli Hitler stanowi ciągły punkt odniesienia, to oznacza, że stanowi przeszłość, która nadal ma posiada znaczenie dla współczesności, przeszłość, z którą nieustannie należy się mierzyć. Powodem jest to - jak sądzę - że postawiła ona przed człowiekiem pytania, na które odpowiedź ma zasadnicze znaczenie, nie tylko w kontekście Niemiec w XX wieku, ale dla świata współczesnego w ogóle.

\section{Biografie Hitlera}

Nie dziwią więc powojenne próby zmierzenia się z „fenomenem” Hitlera na różnych płaszczyznach, znajdujących swoje odzwierciedlenie przede wszystkim w jego biografiach ${ }^{9}$. Można powiedzieć, że wizja Hitlera zawiera się w spektrum od przekonania, że wszystko, co się wydarzyło, było jego dziełem, aż do interpretacji, że był jedynie trybikiem w wielkiej machinie. Zwolennicy pierwszego ujęcia kierują się mniej więcej takim rozumowaniem: „Hitler sprawował władzę, poznanie osobowości Hitlera może dać odpowiedź na pytanie, dlaczego takie, a nie inne zjawiska miały miejsce podczas jego rządów (...) Rozumowanie jest proste: poznaj osobowość dyktatora, a po-

6 Oskarżeni odpowiadali na zarzuty zbrodni przeciwko pokojowi, zbrodni wojennych oraz zbrodni przeciwko ludzkości. 12 oskarżonych zostało skazanych na karę śmierci przez powieszenie (Göring popełnił samobójstwo przed wykonaniem wyroku, Bormann skazany został in absentio). Podstawą prawną tzw. procesów norymberskich stanowiła przede wszystkim Deklaracja Londyńska z 8 sierpnia 1945 roku. Por. Materiały norymberskie: umowa, statut, akt oskarżenia, wyrok, radzieckie votum, oprac. T. Cyprian, J. Sawicki, Warszawa 1948; Encyclopedia of the Holocaust, red. I. Gutman, London-New-York 1990, t. IV, s. 1488-1518.

Odbyły się dwa procesy oświęcimskie, w czasie których osądzono i skazano przede wszystkim pracowników obozu Auschwitz-Birkenau. Pierwszy z nich miał miejsce w Polsce (24 XI - 16 XII 1947), drugi we Frankfurcie nad Menem (20 XII 1963 - 10 VIII 1965). Por. T. Cyprian, J. Sawicki, Siedem wyroków Najwyższego Trybunału Narodowego, Poznań 1962, a także szczegółowe opracowanie procesu frankfurckiego: D. O. Pendas, The Frankfurt Auschwitz Trial 1963-1965. Genocide, History, and the Limits of the Law, Cambridge 2006.

J. Assmann, Pamięć kulturowa..., s. 91.

Na temat biografii Hitlera: M. Kater, Hitler in a Social Context, „Central European History” 1981, nr 14, s. 243-272; G. Schöllgen, Das Problem einer Hitler-Biographie, „Neue politische Literatur" 1978, nr 23, s. 421-434; J. Lukacs, The Hitler of History, New York 1977. Przegląd literatury na temat Hitlera: G. Schreiber, Hitler. Interpretationen 1923-1983. Ergebnisse, Methoden und Probleme der Forschung, Darmstadt 1984. 
znasz jego dyktaturę “4 ${ }^{10}$. Jak słusznie zauważa I. Kershaw, w konwencjonalnej biografii zawarte jest implicite pytanie o historyczną wielkość, które w przypadku Hitlera wyrażało się przekonaniem o „negatywnej wielkości” ${ }^{11}$. Zwolennicy drugiego podejścia starają się udowodnić, że Hitler stanowił jedynie element mieszczaństwa, sfrustrowanych kombatantów, marionetkę wielkiego przemysłu. Tego typu podejście było charakterystyczne przede wszystkim dla myślicieli marksistowskich, dla których stanowił on przedstawiciela interesów przemysłu.

Wśród licznych prac poświęconych Hitlerowi, można wymienić biografie m.in.: I. Kershawa ${ }^{12}$, A. Bullocka ${ }^{13}$, J. Festa ${ }^{14}$, B. Hammann ${ }^{15}$, D. Irvinga ${ }^{16}$, P. Rainy ${ }^{17}$, K. Grünberga ${ }^{18}$, W. Masera ${ }^{19}$, G. Knoppa ${ }^{20}$ czy R. Rosenbauma ${ }^{21}$. Jest to oczywiście jedynie kropla w morzu publikacji, które wyliczono na ponad sto tysięcy.

Zajmowane przez biografów pozycje interpretacyjne mieszczą się w spektrum od psychoanalizy do hagiografii, od prac stricte naukowych do powieści sensacyjnych. Jak zauważyła Maria Zmierczak, ,przyjęcie założenia, że skoro sprawował nieograniczoną władzę w państwie, to źródeł polityki należy szukać w poglądach, przeżyciach i psychice Hitlera, zaowocowało badaniami podjętymi przez psychiatrów, psychologów, psychohistoryków i seksuologów. Zajęto się bardzo gruntownie dzieciństwem, wychowaniem, lekturami, kobietami, słowem - wszystkim (...)"22. Efekty tego typu namysłu

10 M. Zmierczak, Spory o Adolfa Hitlera w najnowszej literaturze, „Studia nad Faszyzmem i Zbrodniami Hitlerowskimi" 2003, nr XXVI, s. 345.

I. Kershaw, Hitler, przeł. B. Bandel, Poznań 2001 i 2002. Składa się z 3 tomów: 1889-1936 Hybris, 1936-1941 Nemesis, 1941-1945 Nemesis.

13 A. Bullock, Hitler. Studium tyranii, przeł. T. Ebert, Warszawa 1969. Bullock zrewidował swoje przekonanie o nieistotnej roli ideologii i zmienił stanowisko w pracy: tenże, Hitler i Stalin. Żywoty równoległe, przeł. M. Lipska, J. Mianowski, M. Rudowski, Warszawa 2004.

14 J. Fest, Hitler. Biografia, Warszawa 1995-1996; składa się z 2 części: I. Droga do władzy, II. Führer. Wedle Hermanna Gramla Fest przecenił rolę jednostki w historii i położył zbyt mały nacisk na kontekst społeczny (H. Graml, Probleme einer Hitler-Biographie. Kritische Bemerkungen zu Joachim C. Fest, , Vierteljahrshefte für Zeitgeschichte” 1974, nr 22, s. 75-92.

${ }_{16}$ B. Hamann, Wiedeń Hitlera. Lata nauki pewnego dyktatora, przeł. J. Dworczak, Warszawa 1999.

16 D. Irving, Wojna Hitlera, przeł. B. Zborski, Warszawa 1999 (w j. polskim również inne wydania).

17 P. Raina, Adolf Hitler 1945: koniec legendy, Warszawa 2005.

18 K. Grünberg, Adolf Hitler: biografia, Warszawa 1996; tenże, Adolf Hitler: biografia Führera, wyd. 2 popr. i uzup., Warszawa 1989; tenże, Życie osobiste Adolfa Hitlera, Toruń 1991. W. Maser, Adolf Hitler. Legenda, mit, rzeczywistość, przeł. E. Zigler-Brodnicka, Warszawa 1998. G. Knopp, Hitler - dziedzictwo zła, przeł. R. Turczyn,

R. Rosenbaum, Wyjaśnianie Hitlera. W poszukiwaniu źródeł zła, przeł. A. Siewior-Kuś, Warszawa 2001.

${ }^{22}$ M. Zmierczak, Spory..., s. 345. 
nie zawsze kończyły się szczęśliwymi rezultatami ${ }^{23}$. Próby zrozumienia Hitlera prowadziły do analizy jego postaci przez pryzmat obaw przed chorobą weneryczną, niepewności własnego pochodzenia, choroby psychicznej, kompleksów na tle seksualnym; różniły się także oceny jego inteligencji - od geniusza politycznego, męża stanu, charyzmatycznego przywódcy i uwodziciela tłumów do tępaka, żałosnego uzurpatora, spryciarza.

W pracach biograficznych, które stronią od taniej sensacji, zauważyć można podobny cel. Kershaw stawia sobie za zadanie ujęcie, co było dziełem samego Hitlera, a co „było częścią bardziej ogólnie rozumianego kryzysu europejskiego" ${ }^{24}$, podkreślając, że prawdopodobnie wygodniejsze byłoby zrezygnowanie z poszukiwań przyczyn „niemieckiego nieszczęścia” poza Hitlerem, lecz jednocześnie byłoby uproszczenie. Zakładając, że całe jestestwo Hitlera zostało podporządkowane roli Führera, Kershaw chce scharakteryzować jego władzę, która jedynie częściowo pochodziła od niego samego

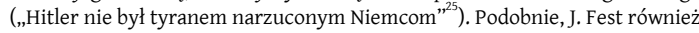
podniósł kwestię wielkości Hitlera, a jego odpowiedź była ambiwalentna. Z jednej strony bowiem, ,wszelkie rozważania nad osobowością i karierą Adolfa Hitlera po dłuższym czasie prowadzą do stałego uczucia moralnej odrazy” $^{26}$, z drugiej natomiast „sprawy, które się wydarzyły w jego czasach, byłyby bez niego niewyobrażalne, w każdym aspekcie i w każdym szczególe”. Guido Knopp podkreślał, że „im więcej wiemy o Hitlerze, tym trudniej nam wyjaśnić jego fenomen, tym bardziej wymyka nam się z rąk" ${ }^{27}$. Nie jest on jednak demonem, lecz czymś przesadnie niemieckim. Był chorym łajdakiem, ale skupienie się na jego cechach psychicznych stanowi zbyt łatwe wyjaśnienie, gdyż „pomogliśmy mu [my, Niemcy] zdobyć władzę," ${ }^{\text {"2 }}$. Celem jednej z najbardziej znanych biografii, autorstwa A. Bullocka, jest także próba odpowiedzi na pytanie, ,jak wielką rolę odegrał Hitler w historii Trzeciej Rzeszy" ${ }^{29}$ oraz jaki jego obraz był prawdziwy.

\section{Anatomia Hitlera Percy'ego Schramma}

Na tym tle należy rozpatrywać próbę przedstawioną przez Percy'ego Ernsta Schramma (1894-1970) ${ }^{30}$. Schramm osiągnął uznanie przede wszyst-

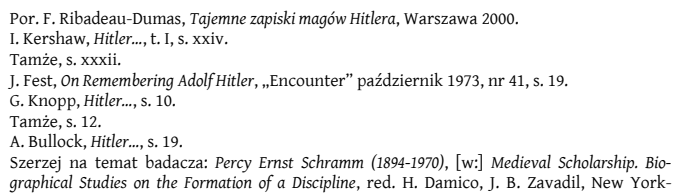


kim jako badacz średniowiecza w kontekście symboli politycznych oraz rytuałów. Związany z Uniwersytetem w Heidelbergu, gdzie pod kierunkiem Karla Hampego doktoryzował się pracą Studien zur Geschichte Kaiser Ottos III (1922), a następnie habilitował - Kaisertum, Rom und Antike vom Ende des 9. bis zum 12. Jahrhundert (1924). W czasie studiów w Heidelbergu zawarł znajomość z Ernstem Kantorowiczem, również uczniem Hampego; wspólnie studiowali także u Friedricha Baethgena. W 1929 roku Schramm osiadł w Getyndze, w której zamieszkiwał aż do śmierci, gdyż na tamtejszym uniwersytecie otrzymał profesurę w zakresie historii średniowiecznej i nowożytnej. W 1939 roku wstąpił do NSDAP, a w czasie wojny prowadził dziennik wojenny Wehrmachtu, znajdując się dość blisko kwatery głównej. Po wojnie został poddany procesowi denazyfikacji.

Z Ernstem Kantorowiczem łączyły go nie tylko studia w tym samym mieście, lecz również zainteresowania badawcze. Obydwaj rozwinęli podobne podejście do historii średniowiecznej, a także zajmowali się zbliżonymi problemami. Do najważniejszych prac Schramma należą tutaj: Kaiser, Rom und Renovatio. Studien und Texte zur Geschichte des römischen Erneuerungsgedankens vom Ende des karolingischen Reiches bis zum Investiturstreit (1929), Geschichte des englischen Königtums im Lichte der Krönung (1937), Der König von Frankreich. Das Wesen der Monarchie vom 9. zum 16. Jahrhundert. Ein Kapitel aus der Geschichte des abendländischen Staates (1939), Herrschaftszeichen und Staatsymbolik. Beiträge zu ihrer Geschichte vom dritten bis zum sechzehnten Jahrhundert (1954-56), Sphaira, Globus, Reichsapfel. Wanderung und Wandlung eines Herrschaftszeichens von Caesar bis Elisabeth II (1958). We wskazanym zakresie Schramm był uznanym i cenionym badaczem ${ }^{31}$. Samo wyliczenie tych prac, wskazujące na obszar, w ramach którego poruszał się badacz, zdradza również powinowactwo z Kantorowiczem $^{32}$.

London 1995, s. 147-162; J. Grolle, Der Hamburger Percy Ernst Schramm. Ein Historiker auf der Suche nach der Wirklichkeit, Hamburg 1989. Na temat historyków w czasie Trzeciej Rzeszy zob. M. Fahlbusch, Wissenschaft im Dienst der nationalsozialistischen Politik? Die „volksdeutschen Forschungsgemeinschaften " von 1931-1945, Baden-Baden 1999; Paths of Continuity. Central European Historiography from the 1930s to the 1950s, red. H. Lehmann, J. van Horn Melton, New York 1994; Deutsche Historiker im Nationalsozialismus, red. W. Schulze, O. Gerhard, Frankfurt am Main 1999.

„Schramm war in seinen Büchern ein großer Sammler, aber auch ein Virtuose in der Interpretation der gesammelten Objekte und Zeugnisse. Sein wiederholt auch ausgesprochenes Motto lautete: «Die Denkmale schreiben uns die Art vor, wie sie behandelt werden wollen"” (N. Kamp, Percy Ernst Schramm und die Mittelalterforschung, [w:] Geschichtswissenschaft in Göttingen. Eine Vorlesungsreihe, red. H. Boockmann, H. Wellenreuther, Göttingen 1987, s. 361.

Por. E. Kantorowicz, Dwa ciała króla. Studium ze średniowiecznej teologii politycznej, przeł. M. Michalski, A. Krawiec, Warszawa 2007. Na temat życia Kantorowicza zob. J. Strzelczyk, Cis Oceanum et Ultra. Ernst Kantorowicz i jego dzieto, [w:] E. Kantorowicz, Dwa ciała..., s. vii-xxviii. 
Podobieństwa między nimi ${ }^{33}$ doszukiwano się również na zupełnie odmiennej płaszczyźnie ${ }^{34}$, a mianowicie $\mathrm{w}$ sferze politycznej. Uwikłanie Schramma w nazizm było ewidentne, ale jego stopień pozostawał problematyczny. Sytuując go na tle niemieckich intelektualistów, Winfried Schulze uznaje go za przykład zachowania typowego: „Przyznał się, że choć nie był członkiem partii, codziennie zadawał sobie pytanie, jak bardzo zgadza się z jej celami i nigdy nie mógł osiągnąć ostatecznej odpowiedzi. Jednego wieczora zgadzał się, a innego był krytyczny; ta ambiwalencja zdaje się być czymś typowym dla intelektualistów z tamtych czasów" ${ }^{35}$.

W 1962 roku Schramm opublikował pierwszą książkę, która nie należała w zasadzie do obszaru jego dotychczasowych zainteresowań naukowych, tj. Hitler als militärischer Führer. Erkenntnisse und Erfahrungen aus dem Kriegstagebuch des Oberkommandos der Wehrmacht, bazującą na jego doświadczeniach związanych z prowadzeniem dziennika wojennego. Dwa lata później ukazała się Anatomie eines Diktators, która pierwotnie została wydana jako seria sześciu obszernych artykułów w tygodniku „Der Spiegel” ", później zaś jako obszerny, około stustronicowy wstęp do książki Hitlers Tischgespräche im Führerhauptquartier $1941-1942^{37}$. W języku angielskim został on opublikowany jako osobna książka ${ }^{38}$.

By zobrazować akcenty, jakie Schramm położył w swojej interpretacji, zacznijmy od wyliczenia niektórych kwestii, którymi badacz zajął się w swej analizie Hitlera. Są to m.in. stosunek do rodziny i kobiet, sztuki, tańca, muzyki, jego pamięć i wiedza, stosunek do nauk przyrodniczych i medycyny, wizje przyszłości, wiedza techniczna i militarna czy zachowanie wobec współpracowników. W pierwszej części swoich rozważań, Schramm koncen-

${ }^{33}$ Podobieństwa zwięźle oddał N. F. Cantor: „Zarówno Schramm, jak i Kantorowicz zostali wykształceni wedle dominującej szkoły Geistesgeschichte. Obydwaj interesowali się liturgią i dworską ideologią monarchii. Obydwaj pragnęli w innowacyjny sposób wykorzystać historię sztuki jako materiał źródłowy. Obydwaj interesowali osobowością historyczną, starając się odnaleźć za ideami działającą osobę. Jest to prawdziwe szczególnie w przypadku Kantorowicza, lecz także Schramm starał się robić to w wielkim stylu, pisząc z werwą i elokwencją na neowiktoriańską modłę" (Zob. N. F. Cantor, The Nazi Twins: Percy Ernst Schramm and Ernst Hartwig Kantorowicz, [w:] tenże, Inventing the Middle Ages. The Lives, Works, and Ideas of the Great Medievalists of the Twentieth Century, New York 1991, s. 83)

Zob. tamże, s. 79-117.

W. Schulze, German Historiography, 1930s to 1950s, [w:] Paths of Continuity. Central European Historiography from the 1930s to the 1950s, red. H. Lehmann, J. van Horn Melto, New York 1994, s. 28 .

36 P. E. Schramm, Adolf Hitler. Anatomie eines Diktators, „Der Spiegel” 1964, nr 5, s. 40-61. Kolejne części: 1964 , nr 6, s. 37-51; 1964, nr 7, s. 42-56; 1964, nr 8, s. 55-67; 1964, nr 9, s. 39-49; 1964, nr 10, s. 48-60.

${ }^{37}$ H. Picker, Hitlers Tischgespräche im Führerhauptquartier 1941 1942, ed. P. E. Schramm, Stuttgart 1963.

38 P. E. Schramm, Hitler: the Man and the Military Leader, Chicago 1971. 
truje się również na szczegółach anatomicznych: „kąsające spojrzenia”, któremu mało kto umiał sprostać, umiejętności zezowania czy wrażliwości na słońce. Dowiadujemy się, że Hitler kochał góry przy jednoczesnej niechęci dla morza, wrażenie wywierało „wesołe usposobienie, i jego wyrozumiałość, którą okazywał podwładnym w razie popełnienia w jego obecności nietaktu”. Lubił też obserwować zwierzęta, przede wszystkim swoje dwa owczarki Blondi i Bellę. Na czele sztuki stawiał architekturę, lubił ładne dywany i wieszał na ścianach obrazki. Duże znaczenie miały dla niego kwiaty. By uzyskać jasność myśli, kilometrami spacerował po pokoju. Gwiaździste niebo wywierało na nim duże wrażenie, charakteryzował się również niezwykłą wyobraźnią. Wiemy także, że w 1942 miał grypę, a poza tym był raczej zdrowy. Takich spostrzeżeń można by cytować mnóstwo, ukazując obraz wyłaniający się z rozmów „przy stole” w kwaterze głównej wedle Percy'ego Schramma ${ }^{39}$.

Publikacja Anatomii nie przeszła bez echa, zwłaszcza, że w swym pierwszym wydaniu stanowiła "temat z okładki” jednego z najpoczytniejszych niemieckich tygodników. Ostrze swej krytyki skierował na zaproponowaną przez historyka analizę m.in. Eric Voegelin w swoich wykładach na Uniwersytecie Monachijskim, opublikowanych najpierw w języku angielskim jako Hitler and the Germans, a następnie w języku ojczystym Voegelina (Hitler und die Deutschen). Główny zarzut, jaki można tutaj postawić Schrammowi, to brak rozeznania w tym, co jest istotne, a co nie. Jak ironicznie wskazuje Voegelin, Schramm „nie mówi, czy [Hitler] potrafił ruszać uszami. Nie ma także żadnej informacji, czy potrafił włożyć do ust duży palec od nogi “" U Schramma roi się bowiem od podobnych "doniosłych" obserwacji ${ }^{41}$, a ich trywialność poraża czytelnika.

Voegelinowską krytykę Schramma z pewnością można określić mianem ostrej. Ów badacz średniowiecza jest dla Voegelina jednym z trzech przypadków „stoczenia się w otchłań”: po pierwsze, owemu stoczeniu uległa sfera akademicka, której zniszczenie Voegelin ukazuje właśnie na postaci Schramma, po drugie, sfera kościelna, zarówno w przypadku kościoła ewangelickiego, jak i katolickiego; po trzecie - sfera prawa ${ }^{42}$.

39 Na temat szczegółów powstania tego zbioru zob. P. E. Schramm, Vorwort und Erläuterungen, [w:] H. Picker, Hitlers Tischgespräche..., s. 13-25.

40 E. Voegelin, Hitler and the Germans, przeł. D. Clemens, B. Purcell, Columbia and London 1999, s. 116.

${ }^{41}$ Inne krytyki zob. np. A. Wucher, Hitlers gar liebliches Spiegelbild, oder Mißglückte ,Anatomie eines Diktators', „Süddeutsche Zeitung“, 7-8 marca 1964.

42 Por. F. Ryszka, Państwo stanu wyjątkowego, Wrocław 1985; G. Agamben, Stan wyjątkowy, przeł. M. Surma-Gawłowska, Kraków 2008, a także: tenże, Co zostaje z Auschwitz?, przeł. S. Królak, Warszawa 2008. 
Schramm porusza się w obrębie „drugiej rzeczywistości“, stworzonej w jego umyśle, która przesłania mu pierwszą, prawdziwą. Austriacki pisarz, Heimito von Doderer w wielu swoich pracach opisywał tę specyficzną ślepotę u ideologów, którzy nie chcą widzieć rzeczywistości, lecz narzucić na nią własny obraz. Dorosz podkreśla, że ,jednymi z pierwszych (...) był Robespierre uważany za wcielenie cnoty i Saint-Just nazywany aniołem śmierci. Przeszło sto lat później w ich ślady poszli bolszewicy, a później naziści (...)" Schramm to pars pro toto postępującego upadku życia intelektualnego Niemiec $^{44}$, które nie potrafi sobie z Hitlerem poradzić, tj. zaproponować jego sensownej interpretacji. Ów intelektualny stan określić wypada mianem głupoty. Wbrew pozorom, głupota ${ }^{45}$ to nie niedostatek rozumu, lecz oznaka porażki inteligencji, spowodowanej porwaniem się na czyny, które przerastają jej możliwości. Idąc dalej za wskazówkami Roberta Musila:

Głupota wyższego rzędu jest właściwą chorobą ludzi wykształconych (żeby jednak uprzedzić nieporozumienia: oznacza ono niedokształcenie, fałszywe wykształcenie, wykształcenie zdobyte opatrzną drogą, zachwiane proporcje między materią a siłą wykształcenia) (...) sięga ona niekiedy szczytów uduchowienia; (...) przyczynia się do intensywności życia intelektualnego, zwłaszcza jednak do jego chwiejności i jałowości ${ }^{46}$.

Voegelin posuwa się nawet do tego, że wskazuje na podobieństwa między Hitlerem a analizującym go Schrammem, podkreślając ich niezdolność do prawdziwego wykształcenia. Głupota stanowi „duchową glebę współczesnej dehumanizacji”, i tak rozumiana stanowi nierozwiązany problem niemieckiego mieszczaństwa, który był podzielany przez Hitlera, Schramma czy Haeckela, problem, który nie został rozwiązany wraz z upadkiem Trzeciej Rzeszy, skoro w 1964 roku można było go odnaleźć u Schram$\mathrm{ma}^{47}$. Degrengoladę mieszczaństwa Tomasz Mann wyraził słowami Serenusa Zeitblooma: „Odczuwało się to bardzo mocno, stwierdzało obiektywnie: utratę na skutek wojny ogromnych wartości przez indywiduum jako takie, bezduszność, z jaką życie przewalało się podówczas ponad jednostką (...) wojna i tu, jak w wielu innych dziedzinach, po prostu tylko dokończyła, wyjaskra-

${ }_{44}$ K. Dorosz, Farsa historii, „Przegląd polityczny” 2009, nr 95, s. 97.

44 Wartościową pracą na temat „upadku mandarynów” jest: F. K. Ringer, The Decline of German Mandarins, Cambridge 1969.

${ }^{45}$ Nie ta głupota poczciwa, lecz „ambitna głupota wyższego rzędu” wedle R. Musila.

${ }^{46}$ Por. R. Musil, O głupocie, [w:] tenże, Czlowiek matematyczny $i$ inne eseje, przeł. J. Buras, Warszawa 1995, s. 262.

${ }^{47}$ E. Voegelin, Hitler and..., s. 145. 
wiła, skonkretyzowała drastycznie wszystko to, co torowało sobie drogę i stanowiło podstawę nowego stosunku do życia ${ }^{\text {“48 }}$; a w eseju opublikowanym w 1939 roku - „mówiłem o europejskim zeszmatławieniu: i rzeczywiście, naszym czasom udało się zeszmatławić tak wiele (...) Przyniosły także skundlenie wielkiego człowieka“" ${ }^{49}$.

Teza Schramma o niemożności wyrażenia tego, kim jest Hitler, wydaje się jednak wątpliwa. Przede wszystkim, terminy takie, jak „niewysłowiony“, "niewypowiedziany“, „nieopisany“ odnosiły się przede wszystkim do Boga i stanowiły rodzaj wielbienia w milczeniu (euphemein) ${ }^{50}$, i przenoszenie ich na postać Hitlera wydaje się co najmniej dwuznaczne. Twierdzenie, że był on osobą nie do opisania, wyjątkową i nieogarnioną, jest bowiem formą oddania chwały. Tymczasem jednak wielu badaczy, przede wszystkim biografów, jest w stanie ująć postać Hitlera we właściwych kategoriach, by wspomnieć choćby na występujące u A. Bullocka: „skłonność do samodramatyzowania“, „wrażliwość na nastrój tłumów“, „wyrachowanie i fanatyzm“, „doskonały aktor“. Okazuje się zatem, że istnieją słowa, które w jakiś sposób oddają „istotę" Hitlera.

Innym w formie, choć z ducha tym samym sposobem wyrażenia owej „niewysłowioności“ stanowi teza o demoniczności. Schramm również jej ulega, odnosząc się do fragmentu $Z$ mojego życia. Zmyślenie i prawda Goethego, którym zakończył cykl Anatomia dyktatora: „Patrząc na przeszłe czasy, Goethe pisał o demoniczności, lecz brakowało mu doświadczenia, które umożliwiłoby mu pojęcie, jak przerażające, jak szatańskie, jak piekielne może ono być. My wiemy, lecz nie ma słów w naszym języku, by oddać wymiar demoniczności, który przyjął formę Adolfa Hitlera“" ${ }^{\text {“51 }}$. Wedle Voegelina, odniesienia do demoniczności pozwalają uniknąć krytyki ducha ${ }^{52}$, a to właśnie zepsucie ducha stanowi przyczynek do tego typu wydarzeń.

Próba wyjaśnienia historii Niemiec w odniesieniu do demoniczności nie jest jednak nowa - przedstawił ją w Doktorze Faustusie T. Mann. Opisana przez Manna "choroba duszy“ to przede wszystkim brak granicy między dobrem a złem, zdrowiem a chorobą, geniuszem a upadłym szaleńcem, a zatem pomieszanie języka. Szaleństwo, czyli choroba, staje się warunkiem geniuszu, a także niezbędnym dopełnieniem zdrowia. Wedle Manna diabeł jest

\footnotetext{
T. Mann, Doktor Faustus. Żywot niemieckiego kompozytora Adriana Leverkühna, opowiedziany przez jego przyjaciela, przeł. M. Kurecka, W. Wirpsza, Warszawa 2008, s. 375.

T. Mann, Brat Hitler, [w:] tenże, Moje czasy, przeł. W. Kunicki, Poznań 2002, s. 387.

Zob. G. Agamben, Co zostaje..., s. 31-32.

P. E. Schramm, Vorwort..., s. 119.

E. Voegelin, The German University and the Order of German Society: A Reconsideration of the Nazi Era, "The Intercollegiate Review" 1985, Spring-Summer, s. 14.
} 
„postacią bardzo niemiecką “" ${ }^{53}$, nie należy jednak - jak sądzę - rozumieć tego dosłownie, lecz mając na względzie duchową sytuację Niemiec na początku XX wieku. Teza o (demonicznym) duchu niemieckim, odmiennym od wszystkich innych, w sposób wyraźny zarysowała się w nurcie interpretacji nazizmu przez pryzmat Sonderweg ${ }^{54}$.

Parafrazując tytuł pracy Richarda Weavera, „Schramm ma swoje konsekwencje” - przyjęcie jego analizy jako zbioru „faktów”, „dokumentu” ukazującego to, jakim Hitler był naprawdę, oznacza jednocześnie rezygnację, a raczej niezauważenie nakreślonych powyżej problemów. Autor Anatomii wyczarowuje obraz dyktatora, który swoją pamięcią, nosem jak „piramida” i zdolnością rozpoznawania ludzi po chodzie uwodził tłumy. Czy jednak jest naprawdę sedno tego, co się stało? Rozsądek i historia podpowiadają, że nie.

Hitler nie był elementem obcym, diabolicznym i niespodziewanym, stanowił bowiem wykwit chorego społeczeństwa, a próby przedstawienia go w nakreślonych wcześniej kategoriach prowadzą do uczynienia z niego alibi. „Odpowiedź, że Hitler w genialny sposób oszukał wszystkich, nie do końca jest zadowalająca“" ${ }^{55}$, dlatego skłonność Niemców ku Hitlerowi jest o wiele ważniejsza niż sam Hitler. Ponieważ społeczeństwo go - mniej lub bardziej świadomie - „wyhodowało”, nie da się oddalić pytania o odpowiedzialność tejże wspólnoty za samą siebie i podejmowane w jej imieniu działania. Ma ono charakter uniwersalny i nie dotyczy wyłącznie Niemiec, lecz każdej wspólnoty politycznej.

Bez wątpienia wszelkie próby uchwycenia „fenomenu” Hitlera muszą zawierać pytanie o relację pomiędzy nim jako jednostką a całością, jaką są Niemcy. Pomysł Anatomii dyktatora Schramma wydaje się być już w swoim zamyśle chybiony, gdyż koncentruje się na samym Hitlerze, analizując najmniejsze drobnostki, zachowania czy słowa i zawieszając go tym samym w próżni. Tymczasem pytanie o Hitlera, jego właściwości, cechy, charakter

53 T. Mann, Niemcy i naród niemiecki, [w:] tenże, Moje czasy..., s. 392.

"Jako hasło wywoławcze formuła »niemiecka droga odrębna« (deutscher Sonderweg) weszła w niemiecki powszechny obieg około trzydzieści lat temu, natomiast jako pomysł na formułę historiozoficzną, jako problem historiograficzny czy/i wreszcie jako pomysł na referencyjne rozumienie historycznych przypadłości niemieckich - inaczej mówiąc jak „kwestia niemiecka” (deutsche Frage) - organizowała wyobraźnię polityków, intelektualistów oraz historyków w wieku XIX i w ostatnim stuleciu, przede wszystkim od chwili wybuchu pierwszej wojny światowej” (H. Orłowski, Spory o Sonderweg, o niemiecka „drogę odrębna”, [w:] Sonderweg. Spory o „niemiecka drogę odrębna", Poznań 2008, s. 7). T. Mann w wydanych w 1918 roku Rozważaniach czlowieka apolitycznego (Betrachtungen eines Unpolitischen) pisał na przykład: „W duszy Niemiec następuje »donoszenie « duchowych sprzeczności Europy - w sensie zarówno macierzyńskim, jak też walecznym. Jest to jego właściwym narodowym przeznaczeniem (...) Bycie duchowym polem walki europejskich sprzeczności: to jest niemieckie" (Tamże, s. 108).

55 M. Zmierczak, Spory..., s. 351. 
czy charyzmę, jest jednak o wiele istotniejsze, jeśli rozpatrywać je w kontekście Niemiec, więcej nawet - bez tego kontekstu staje się ono nieważne. Nie istnieje bowiem problem Hitlera, lecz Hitlera i Niemców ${ }^{56}$, przyczyn, które pozwoliły mu dojść do władzy, a później ją sprawować, lub - słowami Voegelina - duchowa kondycja społeczeństwa, w którym narodowi socjaliści mogli dojść do władzy ${ }^{57}$.

Jeśli widzieć tę relację w ten sposób, to „wspominana przeszłość staje się znacząca" ${ }^{, 58}$ nie tylko z tego powodu, że należy wskazać winnych i ich osądzić, lecz przede wszystkim dlatego, że być może dzisiejsze społeczeństwo ponosi nadal odpowiedzialność natury politycznej i/lub moralnej za to, co wówczas się wydarzyło. Być może również krytyczna diagnoza kondycji ówczesnego społeczeństwa dokonana przez Voegelina nie byłaby zasadniczo odmienna, gdyby za przedmiot obrać społeczeństwo współczesne. Angelus Novus, wpatrujący się z szeroko otwartymi oczami w przeszłość, „widzi jedną wieczną katastrofę, która nieustannie piętrzy ruiny na ruinach i ciska mu pod stopy" ${ }^{1,99}$, przeczuwając, że jego świat równie łatwo jak wówczas może się obrócić w gruz. 